\title{
Technological Resources in Title 1 Schools: The Development of Preservice Teachers' Professional Identities
}

\author{
Vicky Cardullo \\ Auburn University
}

Professional identity was used to analyze the complex set of technological skills and understanding of pre-service teachers as they developed metacognitive behaviors. Multiple data sources were used to triangulate findings. Luehman's (2007) perspective of professional identity was used to analyze the data using a Case Story of each participant's development of a professional identity as they developed learning opportunities for students in Title 1 schools during their final internship. Findings indicated that the affordances of technology present both opportunities and challenges as pre-service teachers navigate and explore their professional identity while developing learning opportunities for student learning using technology.

\section{INTRODUCTION}

\section{Teaching is a Highly Skilled Profession}

Student teaching is often considered the capstone in teacher preparation programs. Field placement is a critical factor that often promotes both student learning and teacher learning. The school setting can substantially influence pre-service teachers' beliefs, perceptions, and self-efficacy (Zeichner \& Gore, 1990). Typically, research has postulated that school placement causes preservice teachers to reproduce the kinds of teaching they encounter in their field placements (Feiman-Nemser \& Buchmann, 1985; Hoy \& Rees, 1977). During pre-service education students often develop a set of attributes needed for understanding the complex process of teaching (Shulman, 1998). These attributes include an understanding of pedagogical practices and the impact on student learning, their ability to organize and manage student learning, and their ability to reflect on reflective practices (Shulman \& Shulman, 2004). A person's identity emerges from their personal experiences and the refinement and adjustment of this knowledge through negotiated experiences within a given community (Wenger, 1998). Therefore, individual's prior beliefs and knowledge act as a filter for the development of one's identity.

Reflection is a critical process in the development of professional identities among preservice teachers. It requires a cyclical process of monitoring and revising ideas and actions. Using the construct of the preservice teacher's voice to examine changes in the contribution in a Title 1 school during their final internship the researcher was able to determine the relationships between the factors associated with the implementation of technological resources and the development of professional identities of the preservice teachers.

Luehman's lens of professional identity was used to analyze the complex set of technological skills and understanding of pre-service teachers from a southeastern university placed in their senior internship 
in Title 1 schools. Identity has been defined by many scholars (Gee, 2005; Lave, Wenger, \& Wenger, 1991; Lemke, 2000) as the identity attached to a person by oneself or by others (Gecas, 1982). Professional identity is understood as part of the social identity and relates to work based on self-concepts (Slay \& Smith, 2011). Many scholars share many common characteristics of professional identities (i.e., socially constructed, formed and unformed concepts, and diverse experiences). "The focus on professional identities affords a lens in which the breadth of one's experiences is considered in light of how they impact one's professional practices, values, beliefs, and commitment" (Luehmann, 2007, p. 827). New teachers or preservice teachers will need to figure out how to connect these multiple ways of knowing or they will fail (Alsup, 2006).

\section{METHODS}

This research took place during the fall semester (16 weeks) as elementary education pre-service teachers completed their final internship in a Title 1 school. Throughout the study, four participants maintained an individual reflective journal, developed lesson plans, wrote a reflective vignette after the completion of their internship, and developed a Case Story of their integration of technology during their placement. In addition, each participant completed a pre and post survey i-MARSI (Cardullo et al., 2017), TPACK Survey (Schmidt, Baran, Thompson, Koehler, Mishra, \& Shin 2009).

This qualitative research utilized a collective case study design using narrative description to explore the relationship between the factors associated with the implementation of technological resources and the development of professional identities of the pre-service teachers interning in Title 1 schools. One of the most significant challenges of conducting qualitative research is determining what is worth analyzing. Coding along themes and topics can help to highlight priorities and provide focus to the process of analyzing qualitative data. Therefore, the researcher utilized Luehman's (2007) perspective of professional identity to position the analysis of multiple data sources: (1) knowledge of self as a professional, (2) locating identify within one's community, (3) managing emotional aspects of identity formation, (4) integrating experiences and theory, and (5) the development of a sense of self-confidence. These five characteristics were used to tell the Case Story of each participants development of a professional identity.

\section{RESULTS}

\section{Barbara}

\section{Knowledge of Self as a Professional}

Barbara (all names are pseudonyms) is a 21 -year-old white female completing her final internship in a Title 1 school. She was placed in a $1^{\text {st }}$-grade classroom with a veteran teacher. The primary, elementary school serves students in grades K-2 with a population of 322 students, 64\% African American and 29\% Caucasian. The school currently has $68 \%$ free and reduced lunch and qualifies for school-wide Title 1 . Her current placement has four Chromebooks in the classroom that are used throughout the day for games, Accelerated Reader, and classwork. All students are given a login in kindergarten that transfers with them through high school using Google docs; all work is accumulated throughout the years to show growth and development in an online portfolio. The school in which she is interning recently invested in a Google Expedition Cart. Google Expedition is an immersive education tool that uses virtual reality to explore the world. The cart currently has a designated Wi-Fi and 30 goggles in the cart for the entire school.

Based on assessments prior to the internship, it is evident that Barbara has an overall high indicator of technology. Her results on the i-MARSI (Cardullo et al., 2017) indicated she has a high score on both the Device Supported Metacognitive Strategies (DSMS) pre-scores 3.9 and post-scores 4.8 and SelfMonitoring Metacognitive Strategies (SMMS) pre-scores 3.0 and post-scores 3.6. Her results indicate a metacognitive awareness and application to support her learning. In addition, Barbara is aware of the need for technological, pedagogical, and content knowledge (TPACK Survey, Schmidt et al., 2009). She has 
strong indicators on the TPACK survey of pedagogical knowledge (PK 4.4) content knowledge (CK 4.3) and pedagogical content knowledge (PCK 4). She is also very aware of student knowledge, device knowledge, and the need to be metacognitive as a classroom teacher.

Barbara discussed her previous experiences with technology (i.e., smart board, projectors) and her comfort level and she realized in her senior year at the university "that using the minimum that technology has to offer is providing [her] students a disservice" (Case Story). She stated that she "realized that day that it wasn't fair to [her] students to not engage in technology just because it was easier for [her] to plan and prepare a lesson" (Case Story). Her long-term school-based experiences appear to have influenced her ability to integrate technology. Barbara noted in her TPACK survey (Schmidt et al., 2009) that all of her education professors impacted her learning using technologies responding agree or strongly agree to all questions of Models of TPACK faculty and teachers. The question asked if professors appropriately model combining content, technologies, and teaching approaches in their teaching. She strongly agreed that her mathematics professor and literacy professor often modeled combining content, technology, and teaching approaches into their teaching. These practices influenced her desire to integrate technology.

\section{Locating One's Identity Within One's Community}

When looking at the development of professional identities of pre-service teachers, it is often critical for them to take on the role of apprenticeship of observation. Typically observing experts in the field (i.e., supervising teacher) develops one's identity within the community. Barbara did not have this experience in her final internship placement because her supervising teacher often saw technology as a "time filler or fun activity" (March, Journal) yet she wanted more. She wanted her students to have experiences to "enhance student knowledge and provide background knowledge beneficial for all students" (March, Journal). Barbara became excited at the proposition of using the Google Expedition to enhance student learning. She was well aware of her students and their level of technology stating "most of our students do not have computers at home and the only technology they see is either mom's [or dad's] cell phone or what we provide them at school" (March, Journal). Barbara realized quickly that the Expedition goggles would be an "incredible resource" (February, Journal) as many students "have never been to the beach" (Vignette).

Barbara often struggled with the development of her professional identity. She postulated that she has an assumed professional identity "I am viewed as a millennial and should have all the knowledge and excitement when it comes to technology" (Case Story). She realized it is her responsibility as a teacher to engage students and prepare them for the world "outside her classroom" suggesting the school system and the resources of the individual school will be the "deciding factor" for implementation. Barbara looked at the affordance of her school (Google Expedition) and the curricula and decided to take on the critical role of apprenticeship and teach the first-grade team how to effectively use the Google Expedition for academic purposes not just play or fun (Lesson Plan). Using Google Expedition, she decided to create an introduction to the research students would be exploring (oceans). The unit on Oceans and zones in which the sea life lived in would be their first expedition. In her final reflection in April she discussed the successes she had implementing Google Expedition but stated: "they have not been used outside of the interns using them and unfortunately we are taking that experience with us, the teachers have no knowledge of the cart or the goggles" (April, Journal). Barbara realized she did have a wealth of technological knowledge as a millennial and she was excited to "try" a new tool for learning.

\section{Managing Emotional Aspects of Identity Formation}

Self-efficacy and emotions were trite throughout her final internship. Barbara often commented on her moments of excitement, nervousness, and her moments in which her students made her proud. Barbara recognized early on the lack of experiences her students had with both technology and content; she believed technology to be an excellent resource for all students. This disposition changed throughout her placement. As she began her journey, she often planned with the mindset of "using the exact same technology she grew up with in school" (Case Story). She positions this statement upon her past 
experiences in school placements in which teachers simply used technology "during centers and rotation when you can allow students the opportunity to jump on the computer and play some math and reading games" (Case Story). She realized it was her role as a teacher to prepare her students and to incorporate technology in a meaningful manner. She was frustrated with the notion of using technology for "fun" or a "time filler" (March, Journal) and quickly sat down and planned a lesson that would enhance student learning providing them with a being there experience. She discussed that it was "scary to hand expensive technology over students" (March, journal) and realized she would need to model expectation of not only the content but also technology. She was so very "proud of how well students followed directions and engaged in the expedition" (April, journal). She was also very grateful for the other intern in first grade who jumped in to help her problem solve a technology issue (devices went to sleep) during her lesson. During the lesson, Barbara took away a pair of goggles from a student who was spoken to on several occasion for "acting silly" during the expedition. At the end of the expedition, Barbara pulled the student aside and discussed with her why she took away her goggles. What Barbara didn't realize was this student was responding to a flight or fight scenario. The student was scared, she was terrified of the sea creatures in the ocean and could not cope with the sensation of "being there" Barbra realized she did not account for this in all of her planning.

\section{Integrating Experiences and Theory}

Metacognitive awareness is essential to teacher education and the development of lessons integrating technology. TPACK draws upon the technological, pedagogical, and content-based knowledge yet Barbra relied heavily on student knowledge of content, technology, and the pedagogical knowledge of technology and content as well as the content knowledge of device and pedagogy (M-TPACK, Wilson et al., 2014). Her metacognitive behaviors of student, content, technology, and pedagogy helped her to be successful even when there was no apprenticeship of observation taking place. She knew ahead of time that she wanted to ensure the lesson went off without having technological issues. She spent the needed time to familiarize herself with the new technology; then she allowed students time to become familiar with the technology before teaching her lesson. She knew it was essential to establish "ground rules" for the devices and allowed students time to explore and ask questions. Her lesson was a success because she was metacognitively aware of student knowledge, technological knowledge, content knowledge, and pedagogical knowledge (M-TPACK, Wilson et al., 2014). She realized how important it was for her to spend the time prior to teaching the lesson "practicing" and becoming "comfortable" with the device. She stated that the early experiences with the device allowed her to troubleshoot some of the issues that would arise during the lesson, and to determine some of the issue's students might have with the devices. As a metacognitive teacher, she was able to provide a being their experience for her students to make connections to the research they were doing with oceans.

\section{The Development of a Sense of Self-confidence}

Barbara took on an apprenticeship role in which she modeled for the first-grade teachers how to use technology effectively in the first-grade classrooms. She had a willingness to try, problem solve and scaffold learning so her students could experience the "ocean virtually" (lesson plans). She used her prior experiences to mold and developed a professional identity of a metacognitive teacher who is aware of her students, the device, the content, and pedagogy. She quickly realized that although she is a millennial, she does not let that define her. She implemented technology because she knew it would enhance student learning, it would provide them a realistic view of the ocean and draw connections to what they saw virtually and what they were researching. As an educator she sometimes realized "easier is not always better" and that proper planning creates success and self-confidence when using technology for learning.

\section{Carol}

Knowledge of Self as a Professional

Carol is a 21-year-old white female completing her final internship in a rural K-4 Title 1 school. She was placed with a first-grade veteran teacher. The elementary school serves 467 students in grades K-4, 
61\% Caucasian, 37\% African American, and 2\% Hispanic. The school currently has 70\% free and reduced lunch and qualifies for school-wide Title 1. Her school placement has three desktop computers, one laptop, 1 whiteboard, one projector, one hovercam and two computer labs with desktop computers. It is important to note that although the school seems to have the technology it has been unusable due to a school-wide virus. The computers are often used for academic testing.

Carol suggested that she had some familiarity with technology as she has used: Google Documents, Microsoft Word, document camera, projector and has limited experience with Smart Boards. Her results of her i-MARSI (Cardullo et al., 2017) indicated that she has an area of strength and an area of weakness. On her Device Supported Metacognitive Strategies (DSMS) pre-scores 4.1 and post-scores 4.1, she indicated a high level of usage yet her Self-Monitoring Metacognitive Strategies (SMMS) pre-scores 1.8 and post-scores 1.9 indicate she lacks the ability to self-monitor her metacognitive strategies. Her results indicate she is metacognitive of her behaviors while reading digital text (i.e., carefully looking at accuracy of information, combining information from multiple websites, thinking about the content) yet she lacks awareness of self-monitoring strategies to support her reading on digital device (i.e., take notes electronically, use features of the device to annotate, underline or circle information, navigate from text to the Internet for additional information) (i-MARSI, Cardullo et al., 2017). Carol is aware of the need for pedagogical content knowledge as well as technological content knowledge as indicated by her TPACK survey (Schmidt et al., 2009). She has strong indicators on the TPACK survey of pedagogical knowledge (4.2) pedagogical content knowledge (4.2) and technological content knowledge (4.2).

Carol discussed her previous experiences with technology (i.e., MyStory app, camera, projector, Smart Board) and originally planned on having her students use the MyStory app "to create a story of themselves, record themselves telling the story, and have peers view it" (Vignette). Carol noted in her TPACK survey (Schmidt et al., 2009) that a previous professor had modeled this in her class and felt it might be a good resource to use in her classroom. In the end, she decided not to use this resource because of a "lack of time to model and implement technology to the degree in which I planned to use it was challenging" (Vignette). The lack of time she had "to properly teach her students how to use these technologies" caused her to change her plans.

\section{Locating One's Identity Within One's Community}

Mentoring is one of the major aspects of teacher education programs (He, 2010). He (2010) believes mentoring is one of the primary factors that determine the success of first-year teachers playing a significant role in shaping the beliefs and knowledge of a prospective teacher (Borko \& Mayfield, 1995). Carol often looked to her supervising teacher for modeling and "expert demonstration" closely observing center rotation, planning, and resources the teacher used. Carol surveyed the resources available at the school she was interning in and realized she was limited due to issues with the devices (school-wide virus). She reflected upon her supervising teacher's use of technology and stated "I was placed with a teacher who knew little about technology" (Vignette). Frustrated with the technology issue, Carol wondered if she could bring technology into the classroom to develop an integrated lesson. When she spoke with her cooperating teacher, the response she received was "it is extremely difficult, if not impossible, to be given a Wi-Fi password to use iPads with or without students accessing them for education purposes" (Vignette). Feeling a little deflated she wondered about other options that might be offered "by the county or by the administration as an alternative solution for teaching the whole class using technology" (Lesson reflection). Feeling as if there were no other options she used the iPads during the center time just as her teacher had in the past. She designed a lesson in which students completed a task and snapped a photo of their work. She felt this provided a record of what the student completed and served as accountability for the center work.

Carol struggled to identify her personal epistemologies often looking to the teacher to initiate, sustain reflectively, and discursive practices. Carol's understanding that teachers hold knowledge positioned her to think it would lend it to fostering or shaping her identity. Carol believed technology was important and

students "have varying levels of experiences using technology" (Vignette) yet her cooperating teacher's "beliefs" impacted her final decision of how she would incorporate technology into her lesson. The 
relationship between Carol's self-efficacy and the cooperating teacher's self-efficacy and lack of technology skills had a mutual causality on Carol's practices.

\section{Managing Emotional Aspects of Identity Formation}

Carol was clearly frustrated with the lack of support and working technology provided by the classroom teacher, school, and district. She felt it was "harder to develop lessons based on school requirements" (Journal). She also felt as if she were "regressing" often stating in her journal that she was not able to actively use technology. She often worried about the infrastructure at the school and reflected on assessment inequities as "during a Scantron session the power went off about seven times causing student disruption 3-4 times during the assessment. Headphones were not working as many devices were experiencing difficulty with sound" (Journal). Many of these issues happened on a daily basis during instruction, and she often felt "these issues take time away from instruction" (Journal). For example, the simple task of using the hover camera to display work created stress as it often quit working or freezes during instruction. She was often frustrated as a classroom teacher because of the lack of time given by the cooperating teacher to teach her lessons. She realized as a preservice teacher that students need time and teachers need to teach "students how to use technology" (Vignette). She realized that her cooperating teacher "definitely didn't allow students to use technology for more than a simple task" (Vignette). Carol felt her lesson was only "semi-successful" because students often failed to see the purpose of taking images of their work (Journal). She felt the time was her biggest roadblock to preparing students to use technology effectively.

\section{Integrating Experiences and Theory}

Carol was metacognitively aware of the need to model, and implement metacognitive behaviors for students to be successful with technology, yet what she did not expect were barriers to her success. She had a cooperating teacher with limited technological ability, a school with a fractured infrastructure and a district that regulated both curriculum and resources. TPACK draws upon the technological, pedagogical, and content-based knowledge yet Carol relied heavily upon her pedagogical knowledge (M-TPACK, Wilson et al., 2014). She became frustrated at the lack of time given to prepare students to use technology effectively, overwhelmed when she attempted to use the technology present at the school and worried about the unknown consequences (assessment, inequities, student development of metacognitive behaviors) (Technological knowledge) (M-TPACK, Wilson et al., 2014). Because of the dichotomy of self and cooperating teacher, Carol often struggled to identify her teacher identity. She relied heavily on what she knew, pedagogical knowledge (M-TPACK, Wilson et al., 2014) was critical, technology knowledge was essential, for self and students, and content knowledge was important, yet she could not pull them all together because she felt she could not "model" metacognition of device. Carol was metacognitively aware of the need to initiate, sustain reflectively, and discursive practices during her teaching. She understood that teachers hold knowledge that fosters the development of teacher identity.

\section{The Development of a Sense of Self-confidence}

Carol took on the role as a student teacher; she often looked to her supervising teacher for support and modeling with a willingness to try and adapt the knowledge she held and the structure she encountered at the school. She often reflected upon her past experiences and past successes with technology and often felt as if she were regressing because of the infrastructure at the school and the lack of "working" resources. Carol struggled to find her identity within the classroom community often assuming her teacher's identity and implementing things the way she did for center time. As a pre-service educator, she realized she would need to balance "student's current ability to use technology" and the time given by her classroom teacher to teach a lesson. She realized the "lack of time to properly teach the students how to use these technologies" caused her to change her lesson plans to meet the constraints given by her supervising teacher. 


\section{Geri}

Knowledge of Self as a Professional

Geri is a 21-year-old white female who completed her final internship in a Title 1 school. She was placed in a third-grade classroom with a veteran teacher. The elementary school serves students in grades K-6 with a population of 353 students, $45 \%$ African American, $40 \%$ Hispanic, and $16 \%$ Caucasian. The school currently has $82 \%$ free and reduced lunch and qualifies for school-wide Title 1 . Her current placement has a Smart Board, four desktop computers, Chromebooks, and often uses PowerPoint, Flocabulary videos, or allows students to record themselves as they are reading and evaluate or "rate themselves" (March, Journal).

Geri has an overall low score on her i-MARSI (Cardullo et al., 2017) Self-Monitoring Metacognitive Strategies section scoring 1.4 pre and 1.4 post. Looking at her scores for Device Supported Metacognitive Strategies her pre-3.5 and post 2.9 fall within the low to average range as well. Geri often relies on several print-based reading strategies (i.e., visualizing, adjusting reading rate, understanding the main points, and deciding what to read closely and what to ignore) (i-MARSI, Cardullo et al., 2017) and never or almost never uses features of the device to support her understanding of digital text (highlighting, annotation, find function, or hyperlinks) (i-MARSI, Cardullo et al., 2017). Geri has an average awareness of technological, pedagogical, content knowledge (TPACK Survey) as she has average scores for pedagogical knowledge (PK 3.4) content knowledge (CK 3.2) and technological knowledge (TK 3.1). She has some understanding of student knowledge, device knowledge, and the need to be metacognitive as a classroom teacher but is often "overwhelmed (with the) notion of integrating technology" (March, Journal).

Geri discussed her previous experiences with technology (Smart Board, QR codes, Kahoot) and her comfort level in which she stated "from a technological standpoint, I consider myself somewhat techsavvy" (Vignette) and I feel that "I am an overall competent tech-user" (Vignette). However, when it comes to incorporating technology in the classroom "I am a deer in the headlights" (Vignette). Her longterm school-based experiences have had a limited impact on her willingness to implement technology in her lesson plans. She frequently states in her journal writing that technology requires time. "To become an expert, I have to spend a lot of time working with the technology... if it takes me more than five minutes to figure it (technology device, tool, app) out. I don't want to spend my night trying to learn how to implement this into a thirty-minute lesson... I don't like wasting time" (Case Story).

\section{Locating One's Identity Within One's Community}

Professional identities develop over time and involve gaining insight of the professional practices, and the value, skills, and knowledge required and practiced within the professional classroom (Chong, Low, \& Goh, 2011). Learning to teach is a long and protracted process, one that should not be rushed (Borko \& Putnam, 1996). Geri did not have the mindset needed to develop an integrated lesson using technologies. She often felt it was "a waste of time" and was often "frustrated when things don't work as planned" (Vignette). Geri often struggled to balance content, pedagogy, and technology stating "I am so focused on making sure the standards and content that my students are going to be tested on are taught that I don't have a lot of extra time in my day to sit down and teach strategies for digital literacy" (March, Journal).

Geri often struggled with the full development of her professional identity "she viewed herself as "technology savvy" (Vignette), yet she felt "uncomfortable" with things that are "unfamiliar" (March, Journal). Technology was her "deer in the headlights" uncomfortable, unfamiliar tool to integrate into lessons to support student digital literacy (Vignette). Geri looked to her "file cabinet" in her brain and searched for information on how to integrate technology effectively. She reflected upon an early technology class in her undergraduate program in which she learned about new tools. She felt there "wasn't a lot of practicality attached to them and felt she did not have the content knowledge to make these new tools useful (Case Story). Geri continued to search her prior knowledge to see how she could take what she was comfortable with and develop an integrated lesson for technology. She reflected this past summer in which her literacy teacher modeled how to use Newsela articles and digital annotation and 
decided to try it. Because she had some familiarity with annotating digitally from her summer coursework Geri invested the time to develop this lesson. She modeled what she wanted them to do (annotation of digital text) and inserted digital questions for them to locate and respond to in their reading. Students were excited, but she quickly realized the digital text could be altered or moved with a drag and drop function. Students quickly became frustrated that their text "got messed up" (Vignette). Upon reflection, Geri realized she should have spent a little more time on this and the "development of an editable PDF" (Vignette). What she did realize throughout this lesson was students needed more time "a thirty-minute lesson isn't enough time for students to master the material, I would spend more time modeling" (Vignette).

\section{Managing Emotional Aspects of Identity Formation}

Self-efficacy, emotions, and the notion of time where some of the factors that impacted Geri's ability to implement technology into lessons during her internship. She was often "overwhelmed" with the workload, "uncomfortable with things she was unfamiliar with" and frustrated because she viewed herself as a "perfectionist" (Case Story). Muddling through all of these emotions she writes a final reflection in her journal:

Reflecting on this semester, I am more willing to integrate technology into the classroom because I have seen a variety of ways to do so. Now that I have been exposed to these new technological integrations, I know that I will have them in the "file cabinet" in my brain to pull from. I know the more I learn about technology, the more inclined will be to use it in the classroom (April, Journal).

Geri identified an area of concern and sought resources to help her become more comfortable with technology. She often looked to her supervising teacher and the technology specialist at the school. She felt the exposure to the technology and the development and alignment of content made the integration more "practical" when integrating technology into the classroom curriculum.

\section{Integrating Experiences and Theory}

Keen (2007) notes the importance of familiarity with technology and ISTE (2000) contends that teachers should be able to design appropriate learning opportunities that use technology to enhance instructional strategies. Geri felt this was a daunting multifaceted perspective that often left her frustrated and overwhelmed (Hutchison \& Reinking, 2011). Lack of time, lack of professional development, and the ability to teach content and integrate technology are some of the barriers that impacted Geri throughout her internship. Many of these barriers are the cornerstone of preservice teacher's preparation in their undergraduate programs (Hutchison \& Reinking, 2011) yet Geri felt frustrated as she drew upon her previous experiences often feeling like she wasn't adequately prepared to integrate digital technologies for instruction (Case Story) effectively. Geri possessed functional knowledge about technology stating that she was an "overall competent tech-user" (Case Story). However, she lacked the pedagogical purpose. Specifically, how she could not leverage technology for pedagogical purposes, which indicates she lacked technological pedagogical content knowledge (Koehler \& Mishra, 2009).

\section{The Development of a Sense of Self-confidence}

Geri relied on past experiences to integrate technology often feeling that it was time-consuming. Her scores on the i-MARSI (Cardullo et al., 2017) were relatively low for her Self-Monitoring Metacognitive Strategies (Pre and Post 1.4) and within the low to mid-range for Device Supported Metacognitive Strategies (Pre-3.5 and Post 2.9). A necessary prerequisite for selecting a metacognitive strategy is basic metacognitive knowledge about which learning strategies are beneficial. Metacognition is the ability to evaluate one's own learning and is considered to be an important component of self-regulated learning (e.g., Pintrich, 2000), and is associated with academic monitoring, strategy use, and motivation (e.g., Sperling, Howard, Staley, \& DuBois, 2004). Geri lacked the ability to implement technological tools into 
her current curriculum because she felt ill-prepared and often frustrated with the time needed to learn the tools and often wondered "if the hassle is really worth the investment" (Case Story).

\section{Pam}

Knowledge of Self as a Professional

Pam is a 21-year-old white female completing her final internship in a Title 1 school. She was placed in a kindergarten classroom with a veteran teacher. The primary, elementary school serves students in grades K-2 with a population of 900 students, 58\% Caucasian, 37\% African American and 5\% Hispanic. The school currently has $57 \%$ free and reduced lunch and qualifies for school-wide Title 1 . Her current placement has Promethean Activboard, document camera, and a class set of iPads. All teachers have a MacBook and a designated desktop computer for the Promethean board. She stated, "technology was an integral part of classroom instruction" (Case Story).

Pam has a high level of Device Supported Metacognitive Strategies (Pre 4.1 and Post 4.0) (i-MARSI) and medium average scores on the Self-Monitoring Metacognitive Strategies (Pre 2.8 and post 2.9)(iMARSI, Cardullo et al., 2017). Her results indicate an average awareness of Self-Monitoring Metacognitive Strategies (SMMS), which can be thought of as metacognitive tools used to support and sustain responsiveness to reading or metacognitive regulation (i.e., taking notes electronically, using features of the iPad to listen to the text annotations, using reference tools, electronic dictionary, adjust font size, using the search feature to look for key terms). Whereas she had relatively high scores on Device Supported Metacognitive Strategies (DSMS), which can be thought of as supportive tools aimed at sustaining responsiveness to reading or metacognitive knowledge (i.e., setting a purpose, looking at the accuracy of information, previewing text for content by scrolling, paying attention to text features (hyperlinks, bold, color or italicized text), making decisions in relation to what to read carefully or closely) to enhance reading comprehension. Pam is aware of the need for pedagogical, technological, content knowledge. She has strong indicators on the TPACK survey technological knowledge (TK3.3) pedagogical knowledge (PK 4) content knowledge (CK 4.5) and pedagogical content knowledge (PCK 4). She is metacognitively aware of the developmental needs of her students, the technological abilities and developmental appropriateness of technology use in the classroom, and the foundational skills kindergarten students need to be successful.

Pam discussed her previous experiences with technology (i.e., iMovie, QR Codes, SmartBoards, Kahoots, Promethean Board) and stated she often felt "confident" and it was often "easier to incorporate when students can do things such as read supplementary text or create a presentation" (TPACK free response question). Pam noted that all of her education professors impacted her learning using technology. She agreed that all professors modeled content, technology, and teaching approaches into their teaching. She felt these experiences provided alternative opportunities to learn and integrate technology.

\section{Locating One's Identity Within One's Community}

The role of apprenticeship of observation was critical for Pam as she entered her final internship placement in a kindergarten classroom. She commented, "on the first day of my internship one of the teachers at the school showed the cooperating teacher and (Pam) how to access the reading curriculum online so they could show (curriculum) materials online for student learning" (Case Story). She stated that after a quick tutorial she felt "confident" (Case Story). Pam commented on the day to day routines of using technology in the classroom. She postulated that technology was used frequently, stating the classroom teacher and she used it daily as a part of classroom instruction. The technology was often incorporated into center time. What she felt is in parallel to this, she reflected that as prevalent as technology was in the classroom, she found that students did not have the opportunity to interact with it in a way that was meaningful (Reflection) and most technology use was by the teacher or herself as the classroom instructor. 


\section{Managing Emotional Aspects of Identity Formation}

Bandura (1982) stated self-efficacy could determine whether an individual will be able to exhibit specific behaviors, will exert sufficient effort, and involves determination and perseverance to overcome obstacles that would interfere with utilizing those innate abilities to achieve goals. Pam displayed selfefficacy as she worried about student behaviors, encouraged technological exploration by more than the classroom teacher, and used the devices to support the mandated curriculum. She found technology to be a means to differentiate and support students who are often developmentally delayed. She wrote in her journal in January that one of her students is developmentally delayed and another student has autism. She stated, "I have found that it is crucial to differentiate instruction" (Journal, January). Toward the end of January, she writes "I have seen firsthand how technology can be useful in differentiating instruction" she discussed a specific student who has limited cognitive ability and discussed the additional scaffolds the iPad provided (i.e., videos, songs,) for each student (Journal, January).

\section{Integrating Experiences and Theory}

Metacognitive knowledge is knowledge of the structure and process of the task to be achieved. In addition, it is knowledge of strategies to achieve the task, and knowledge related to one's abilities and qualities to perform the task. As a metacognitive teacher, Pam was knowledgeable about the development of the cognitive memory and experiences built during her learning activity. Pam drew upon her TPACK experiences (i.e., technological, pedagogical, content) and realized early on in her placement that students were at a disadvantage because the teacher often leads, used, and integrated technology through the teacher's hands. She felt students should have more responsibility in regards to technology but was very mindful of the developmental levels of the students, the mandated curriculum, and the technological skills her students possessed. She realized students did not use technology beyond STAR testing (Vignette) and designed a lesson that would "give students the opportunity to interact with technology during a lesson" (Vignette). Before starting the activity, she reminded students of handling procedures and active listening. Students were responsible for removing the iPads from the cart, turning on the iPads, and locating the app (Observation). The entire time Pam was cognitively aware of her student's ability to perform the task and strategically scaffolded wherever needed.

Pam was acutely aware of the nuances needed to execute this lesson, she strategically planned and executed steps needed for students to be successful. She commented in her reflection that there were several hiccups (i.e., students could not find the keyboard, could not log onto Kahoot, could not type in the login number) (Vignette). However, she realized the goal of her lesson was "to allow the students to use the technology" she stated, "I wanted the students to work through some of their frustrations" (Vignette). The opportunity for students to problem solve was a rich learning experience. Her final reflection stated, "while there were a few bumps and obstacles I had to address while teaching it was beneficial overall" (Vignette). She felt the students loved the activity as it kept them engaged in learning, and it required them to practice and problem solve with technology. Pam identified some of the developmental challenges associated with using technology in the kindergarten classroom but remained positive stating "I believe it is worth it to prepare students for the future" (Case Story).

\section{The Development of a Sense of Self-confidence}

Pam took a metacognitive stance in which she often reflected upon her student's developmental levels in regard to content, technology, and pedagogy (M-TPACK, Wilson et al., 2014). She had a willingness to allow her students to participate in academic struggles so they could problem solve and interact with technology. She used her previous experiences and developed the professional identity of a metacognitive teacher as she monitored and scaffolded learning using technology in a kindergarten classroom. She implemented technology because she knew students were at a disadvantage and realized they should be able to interact with the technology on a more personal level of discovery. She realized after watching the students using and putting away their iPads one at a time that she was suddenly encouraged by the level of ownership students took in their learning (Vignette). 


\section{CONCLUSION}

Barbara had many factors that shaped her development of a professional identity (i.e., teacher and student metacognitive behaviors, previous experiences, self-efficacy, curricula) and quickly realized that several factors directly impacted the relationship of her identity (i.e., school resources, student technology skills, support). She realized her emotions drove her feeling of "not feeling equipped" and that although she perceived a struggle with "thinking outside the textbook" to incorporate technology in a meaningful way she successfully used Google Expedition (Case Story). Barbara feels her "attitude" has begun to shift and she is beginning to feel more "confident as she engages and plays with different technology" for learning (Case Story).

Carol had many factors that shaped her development or in her case lack of development of a professional identity (i.e., teacher support, previous experiences, self-efficacy, and school-based resources) and quickly realized several factors directly impacted the relationship of her identity (support, time, constraints). She had a willingness to bring in resources to support student learning and was greeted with teacher comments such as "no outside devices permitted, it will be extremely difficult if not impossible" (Vignette). She often felt overwhelmed because she wanted to do more with technology but was extremely frustrated with the disabled devices due to a school-wide virus and often wondered about student equity and testing. She fell back on her teacher's professional identity and did things as her teacher has done in the past (i.e., taking photos of work using the iPad) (Lesson plans). She felt her lesson was only "semi-successful because some students did not know the purpose of taking the photos" (Reflection). Carol feels "had she been allowed more time to spend preparing the students" this lesson would have been more successful (Reflection).

Geri realized it "took her awhile to get comfortable" with the technologies (March, Journal) and several factors (time, professional development, and the integration of content) impacted her professional identity within the classroom. She realized her emotions impacted her self-confidence level as she was often worried, overwhelmed, and stressed. She felt she has grown and has "more willingness" to integrate technologies but also identified the need to develop a repository of tools in her "file cabinet" in her brain to pull resources from.

Pam had many factors that shaped her development of a professional identity (i.e., previous instructional approaches, curricula, previous experiences) and quickly realized that several of these factors would directly impact her need to become metacognitively aware of her relationship and her identity (i.e., students' technological skills, literacy skills, developmental levels, support). She realized she was encouraged and hopeful for academic struggles, and learning using technology. Pam brought technology into the hands of learners.

Collectively all of the preservice teachers negotiated previous experiences with new experiences to develop their professional identities. They navigated content, disparities in school systems, and inequalities amongst technology. Yet as they planned their lessons they developed a metacognitive stance to assure success regardless of developmental levels, technological skills, and literacy skills. Each candidate approached the integration of technology and the development of content in unique ways, yet all candidates were mindful of the factors that often influence or hinder the ability to integrate technology. All candidates had a willingness to learn and a mindfulness to be purposeful with integration of technology. 


\section{REFERENCES}

Alsup, J. (2006). Teacher Identity Discourses. New York: Routledge.

Bandura, A. (1982). Self-efficacy mechanism in human agency. American Psychologist, 37(2), 122-147. doi:10.1037/0003-066X.37.2.122

Borko, H., \& Mayfield, V. (1995). The roles of the cooperating teacher and university supervisor in learning to teach. Teaching and Teacher Education, 11(5), 501-518.

Borko, H., \& Putnam, R. T. (1996). Learning to Teach. In D. C. Berliner \& R. C. Calfee (Eds.), Handbook of Educational Psychology (pp. 673-708). New York: Macmillan Library Reference USA: Simon \& Schuster Macmillan.

Cardullo, V., Wilson, N., Zygouris-Coe, V., \& Wang, C. H. (2018). i-MARSI iPad Metacognitive Awareness of Reading Strategies Inventory: Using an Inventory to Survey Students Cognitive Monitoring of Strategies. In E. Langran \& J. Borup (Eds.), Proceedings of Society for Information Technology \& Teacher Education International Conference (pp. 1347-1356). Washington, D.C., United States: Association for the Advancement of Computing in Education (AACE). Retrieved May 1, 2018 from https://www.learntechlib.org/primary/p/182703/

Chong, S., Low, E. L., \& Goh, K. C. (2011). Emerging professional teacher identity of pre-service teachers. Australian Journal of Teacher Education, 36(8), 50-64.

Feiman-Nemser, S., \& Buchmann, M. (1987). When is student teaching teacher education?. Teaching and Teacher Education, 3(4), 255-273.

He, Y. (2010). Strength-based mentoring in pre-service teacher education: A literature review. Mentoring \& Tutoring: Partnership in Learning 17(3), 263-275.

Hoy, W. K., \& Rees, R. (1977). The bureaucratic socialization of student teachers. Journal of Teacher Education, 28(1), 23-26.

Hutchison, A., \& Reinking, D. (2011). Teachers' perceptions of integrating information and communication technologies into literacy instruction: A national survey in the United States. Reading Research Quarterly, 46(4), 312-333.

Gecas, V. (1982). The self-concept. Annual Review of Sociology, 8(1), 1-33.

Gee, J. P. (2005). The new literacy studies: From 'socially situated' to the work. Situated Literacies: Reading and Writing in Context, 2, 177-194.

Keen, M. (2007). Implementing Technology to Support SOA Governance and Management. IBM, International Technical Support Organization.

Koehler, M., \& Mishra, P. (2009). What is technological pedagogical content knowledge (TPACK)? Contemporary Issues in Technology and Teacher Education, 9(1), 60-70.

International Society for Technology in Education. (2000). National educational technology standards for students: Connecting curriculum and technology.

Lave, J., Wenger, E., \& Wenger, E. (1991). Situated learning: Legitimate peripheral participation (Vol. 521423740). Cambridge: Cambridge University Press.

Lemke, J. L. (2000). Across the scales of time: Artifacts, activities, and meanings in ecosocial systems. Mind, Culture, and Activity, 7(4), 273-290.

Luehmann, A. L. (2007). Identity development as a lens to science teacher preparation. Science Education, 91(5), 822-839.

Schmidt, D. A., Baran, E., Thompson, A. D., Mishra, P., Koehler, M. J., \& Shin, T. S. (2009). Technological pedagogical content knowledge (TPACK) the development and validation of an assessment instrument for preservice teachers. Journal of Research on Technology in Education, 42(2), 123-149.

Shulman, L. S. (1998). Teaching and Teacher Education among the Professions. 38th Charles W. Hunt Memorial Lecture. AACTE Publications, 1307 New York Avenue, NW, Suite 300, Washington, DC 20005-4701.

Shulman, L. S., \& Shulman, J. H. (2004). How and what teachers learn: A shifting perspective. Journal of Curriculum Studies, 36(2), 257-271. 
Slay, H. S., \& Smith, D. A. (2011). Professional identity construction: Using narrative to understand the negotiation of professional and stigmatized cultural identities. Human Relations, 64(1), 85-107.

Wenger, E. (1998). Communities of practice: Learning as a social system. Systems Thinker, 9(5), 2-3.

Wilson, N., Zygouris-Coe, V., Cardullo, V., \& Fong, J. (2013). Pedagogical frameworks of e-reader technologies in education. In S. Keengwe, (Ed), Pedagogical applications and social effects of mobile technology integration (pp. 1-24). Hershey, PA: Information Science Reference. DOI: 10.4018/978-1-4666-2985-1.ch001

Zeichner, K. G., \& Gore, Y. (1990). Teacher socialization. Handbook of Research on Teacher Education. New York: MacMillan, 329-348. 